\title{
Czech Experience with Broader Case Studies Implementation
}

\author{
Martina Fischerová and Kateřina Půbalová
}

\begin{abstract}
The Czech education system is influenced by various conditions that have impact also on the further development of higher education in the Czech Republic. Within the educational process, the shift from passive learning methods (teaching) to active teaching methods (learning) is still obvious. The shift itself places higher requirements on both pedagogical staff skills and their networking ability Important factor for the teachers is getting real data from Czech companies in order to prepare tailor made case studies from the Czech environment. The main aim of this paper is to highlight and analyze the complexity of experience with case studies implementation into the Czech higher education system from various perspectives of selected stakeholders (university, students, companies).
\end{abstract}

Index Terms-Active teaching methods, case studies, Czech Republic, implementation, teamwork.

\section{INTRODUCTION}

Case studies are used as a common and useful interactive teaching method. With its roots in business schools, many other higher educational institutions implemented cases into their curriculum. Comparing with other countries, the Czech Republic is still in the process of transformation [1].

This paper is presenting hands-on experience with case studies implementation at the Faculty of Business Administration of the University of Economics, Prague (FBA UEP). Focus on feedback and opinion of various stakeholders form a significant part of this paper.

The first part of the paper briefly summarizes the development and current status of the Czech educational system and University of Economics, Prague. The next part consists of the description and analysis of student and teacher prospective. The last part presents research outputs and prospective of companies. The paper names various obstacles in case study implementation from the real experience.

\section{CZECh Higher EducAtion System}

The first changes in the educational system in the Czech Republic in the early 90s came hand in hand with the transition in the society and the political situation. Despite this fact, society in the Czech Republic is still changing and the educational system also requires further modification.

Manuscript received March 1, 2013; revised May 10, 2013. Research and work on this paper has been supported by the Internal Grant Agency at the University of Economics, Prague. The registration number: F3/31/2012.

Martina Fischerová and Kateřina Půbalová are with the Department of Managerial Psychology and Sociology at the Faculty of Business Administration, University of Economics, Prague; Czech Republic (e-mail: martina.fischerova@vse.cz, katerina.pubalova@vse.cz)
Various courses of action have already been taken and many problems have already been solved. However, the process has not been fully finished yet and the importance of its completion is recognized not only by academics, but also by the representatives of ministries concerned with this topic. ${ }^{1}$

The current situation shows that pedagogical approaches still belong to areas where major changes are needed. According to various reports, research and comparative studies [e.g. OECD PISA 2003-2009, OECD Education at a Glance 2007-2011 etc.], the Czech educational system still has not implemented active learning methods well enough.

International comparisons show that Czech students know perfectly what is written in the books, but they do not usually know equally well how to use this knowledge in practice. General feedback from companies also shows that fresh university graduates seem to acquire the soft skills needed for their professional life more from their first employers than from their university experience and studies [2].

The situation at the University of Economics, Prague seems to improve every semester (many new courses focused on or using case studies and other active methods, grants dealing with the topic emerged in the last two years), however, comparing with the reports from other countries that started their transition in the same era (e.g. Baltic countries), there is still a significant gap.

\section{The SignificAnce of TEAmWORK AND CASE TeACHING}

All of the techniques and tools used for enhancing students' teamwork and other soft skills should be carefully led by a lecturer. Structured and prepared team learning and teamwork in classes improve diverse student skills, such as: interpersonal relationship, pro-social behavior and critical thinking [3], and also supports the formation of useful behavioral patterns.

It is obvious that good training in team cooperation leads not only to the emergence of team learning, but also increases individual experience with sharing resources, giving feedback, discussing and reaching a compromise, trying various team roles, etc. Teamwork and team cooperation learning techniques are important complementary tools for other training methods (including teacher-centered ones) used either in the classroom or for home preparation.

Long-term study team cooperation in the courses may also simulate real business life situations in some respects.

\footnotetext{
${ }^{1}$ For further information, please compare the Ministry of Education, Youth and Sports web pages: http://www.msmt.cz/areas-of-work/educational-system.
} 
Students have to work together on given task, communicate and cooperate in order to reach the best possible output.

Case studies as one of active teaching methods foster not only student teamwork, but also their experience with business practice [4].

Teaching cases also develop students' analytical skills, self-expression, presentation, interpersonal and social skills and stimulates critical thinking while making decisions. The learning process comes "inside - out" and places a greater emphasis on personal discovery [5].

All the facts mentioned above have been already confirmed by many lecturers and universities. One of the universities using case studies more than successfully is the Harvard Business School (HBS). Case studies developed at this institution are well-known all over the world, being bought by many higher educational institutions. It is truth that that the HBS' case studies are valuable and widely used, however all of them are not always suitable for all countries and cultures. Especially European and US cultures differ a lot and thus is also needed to prepare tailor-made cases for better understanding of the specific country or regional environment for the students.

\section{UNIVERSITY OF ECONOMICS, PRAGUE}

The University of Economics, Prague (UEP) is a public university. With its 6 faculties it is the most recognized business school in the country. ${ }^{2}$ Broader case studies implementation into the curriculum is one of the university priorities.

The time and experience has shown that there are still some obstacles that should be dealt with. In spite the fact that the active teaching methods are widely used in the courses and students are obliged to work, solve problems and collaborate with classmates in order to strengthen their soft skills and also a critical thinking, detailed cases that need more time to prepare for and then work within the classes still seem to be harder to implement.

One of the reasons might be the fact, that UEP generally does not sort students into different study groups. That means that students can choose any course that fits their study plan and study requirements and in each class they meet different classmates, sometimes even from different specializations.

Compared to other Czech universities, UEP students manage their schedules in a more individualized way and this fact makes teamwork and teaching with cases slightly more complicated.

In this situation is harder to encourage students to work together on projects as they do not know each other well enough at the beginning of the course when they are asked to split into teams. Their motivation is also shaped by their (usually negative) experience from the past and fear of "freeriders". They also know that they may never meet in the same course again [3].

On the other hand, such conditions may help students while giving the final feedback on the teamwork, which is

2 University of Economics, Prague as the only business school in the country that gained "five palms" in the Ed-universal ranking in years 2008-2012. More information is available at: http://www.eduniversal-ranking.com. usually required by the lecturers to help them in giving final grades. Students can be more open on the feedback towards other team members and help to avoid future "freeriding" of some of them by giving low grades and negative feedback.

\section{HELPFUl HiNTS}

One of another reason could be the fact that at UEP it is very common that students already try to get their professional experience while studying. The majority of master's degree students already have a part time job or apply for various summer internships. The chart below shows the results of an on-line survey made in 2010 on a university student community webpage [6]. Survey could be completed only by logged users who get the approval based on their university login details.

Do you have any job while studying at the university?

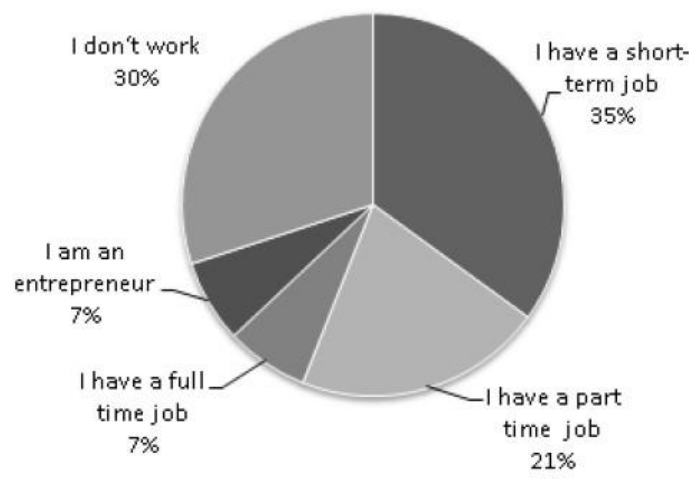

Fig. 1. Nr. of students working while studying at UEP (2010).

The Fig. 1 shows that almost $75 \%$ of UEP students work and study at the same time.

The survey confirms the presumption that while studying the students also trying to become more experienced and get in touch with the business practice. According to their view, the deeper experience will be able to help them after graduation while looking for a long term employment.

At the same time, this situation makes working with "big" case studies that require a home preparation even more complicated. Some of the students do not prepare cases for the class well enough and then the discussion is not so useful and might be also demotivating for other classmates.

\section{ACCEPTANCE of CASE StUdies by EXChange STUDENTS}

While implementing case studies at the UEP is facing problems mentioned above, the students have another possibility to work with cases that is while being on study abroad. The UEP is sending students on study abroad on master degree, with wide range of partner universities all around the world, including prestigious schools in North and South America, Asia, Australia, and of course Europe.

There has been made a survey focusing on study abroad motivation [7]. One part of the survey focused on comparing how students react to the possibility to be educated by case studies and other active teaching methods while studying abroad and it also showed very interesting facts

The explanation of student satisfaction and opinion on the 
host university wasn't mandatory to provide, however more than $90 \%$ of students $(n=287)$ chose to answer, providing direct feedback on the methods and systems used at the receiving institutions.

All of the students answering this question valued the possibility to see and experience different educational system than the one in the Czech Republic. If there were active teaching methods used at the particular university, the students mentioned such situation and always appreciated the chance to be part of the classes.

The most mentioned pros of the study abroad indicated by students were:

1) Classes focused on practical and real issues from practice.

2) Cooperation of the university with valuable companies, thus having experts in classes.

3) Use of teamwork and case studies more than theoretical lecturing.

4) Interesting up-to-date topics brought to classes.

5) Smaller classes providing close student-professor relationship.

6) More intense preparation at home permitting deeper discussion in classes.

From the research can be presumed that even though students usually are not willing to do additional work for classes or "work harder" on projects, if given the possibility to experience active teaching methods, smaller classes and solve real problems from company practice, they appreciate the situation in the end, seeing how useful it is for their future employment and widening their skills.

\section{TEACHERS}

Teachers are very important part of implementing the case studies into university curriculum. As mentioned above, teaching with the use of case studies and other active methods put stronger pressure on teachers' preparation for the classes [8]. There are teaching notes that need to be studied deeply before the class and lecturer needs to be familiar with the overall topic, environment and industry. As well the teachers need to be educated how to use case studies in classes [9].

Providing social status and wage the lecturers are getting for teaching at universities and other higher institutions in the Czech Republic, they usually have another side-job to be able to keep on living or are part of many research groups, teaching at more universities, etc. Time consuming preparation is then sometimes not well-accepted, especially by lecturers who teach the same courses for many semesters and are used to their teaching system.

On the other hand there are many lecturers willing to use the active methods, including the case studies. To be able to do so, they need to overcome some major obstacles. First is the knowledge of the use of the methods, especially because most of the university lecturers are not educated teachers. The UEP is trying to help them in this case by running special teaching courses for doctoral students and young lecturers once every semester. The courses have been very successful so far [10].

Another point are the case studies themselves. First it is not very easy to get a case study suitable for the particular class the lecturers are teaching. As the courses and curricula at every university differ, a case study made and applicable at one university does not necessarily be applicable at another university course, even with the same name. Other cons is the language of the case studies. While most of them are written in English, the language of instruction at majority of the UEP courses is Czech. Majority of the students would have English as first (but not native) language, but it cannot be assumed in advance, the group differs every semester and the language barrier may be big disadvantage.

Most of the problems in implementing the case studies could be overcome by creating tailor made case studies for the purpose of different classes at the UEP by experienced lecturers who already have wide experience with teaching with cases and already started to write them.

The main problem still seems gaining suitable data from the companies. However, supporting those who are able to (and willing to) work on their own case study is definitely seen as the solution to more effective implementing of the cases.

\section{COMPANIES}

In order to find out the opinion and determine the interest of companies for possible collaboration in the development of own case studies, there has been made a research in spring 2012 that approached selected companies that are either corporate partners or are interested in hiring university graduates. It can be expected that the selected sample is interested in the quality of teaching.

In all cases a semi-structured interview was taken by a person responsible for Graduate Relations, Graduate Recruitment, HR marketing or other relevant departments.

All respondents $(n=17)$ agreed that the case study should have their place in education. Most of them mentioned as a main reason the fact that case studies are great tool for simulating business reality.

The majority of respondents also agreed that cooperation in the area of case studies is a very good form for Employer Branding.

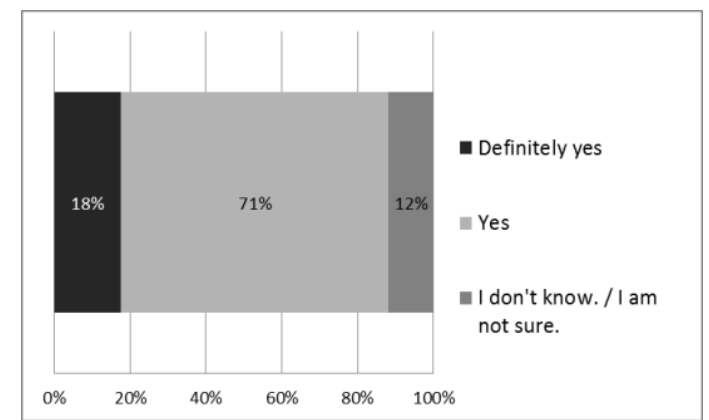

Fig. 2. Do you think that cooperation in case studies' writing is a good form of employer branding?

Respondents also agreed on the fact that, as representatives of the company responsible for recruiting, building a company brand etc., are interested in cooperation in writing local tailor-made case studies. As Fig. 2 showed, a positive response was recorded 14 times, 3 cases were "yes" associated with the word "maybe" or "perhaps". Neutral or negative response hasn't occurred even once. 
At the first glance, the situation looks very optimistic. While continuing with the interviews, the positive responses on significance and general interest in cooperation slowly turned into negative answers on real execution and obstacles.

Unfortunately 8 of above mentioned 14 positive answers on cooperating in writing cases had some "but" in later discussion. Respondents were usually not sure by the opinion of top management, were afraid of time consumption and coordination etc. The representatives were also afraid of providing teachers/case writers by names or real data.

The results of this screening show that even companies have difficulties in delivering materials and people for preparing good local case studies. However, people from real business still are very important stakeholders in the whole case-teaching process and cooperation at least during the data collection forms a crucial part of future success [11].

\section{CONCLUSION}

The implementation of the case studies, together with other active teaching methods, requires a long-term effort.

However, to be able to compete with other universities, it is nowadays necessary to process such implementation. The UEP is trying to keep the pace with the best universities (refer to Ed-universal ranking) and by this trying to introduce the case studies into the curricula. In the last two years there has been made various projects on the case study implementation (Internal Grant Project IGA F3/31/2012, OPPA project donated by the EU, etc.)

From the experience of the project, to implement not only case studies, but active teaching methods in general, it is needed to overcome many obstacles given by the state of the Czech educational system, lack of money for the implementation, language barrier, students' motivation, teachers' motivation and content of curricula at UEP in general.

\section{REFERENCES}

[1] OECD, Education at a Glance 2012, Oecd Indicators, OECD, 2012.
[2] Uplatnění absolventů VŠE a hodnocení absolvovaného studia. (2011). Vysoká škola ekonomická v Praze. [Online]. Available: http://rpc.vse.cz/doc/1050

[3] L. B. Nilson, Teaching at Its Best: Learning in Groups, 2nd ed., Anker Publishing, 2003, pp. 77-85.

[4] H. Košt’álová, T. Králová, and M. Lorenc, Vybrané kapitoly pro rozvoj pedagogických dovedností, 1st. ed., Prague: Oeconomica, 2010, ch. 1, pp. 25-29.

[5] L. L. Mauffette, J. Erskine, and M. R. Leenders, Learning with Cases, 4th ed., London: Ivey Publishing, 2007, ch. 1, pp. 1-9.

[6] VE studies on VE. [Online]. Available: www.vseborec.cz

[7] K. Půbalová, "Study abroad motivation," presented at the ICERI 2012 , 5th International Conference of Education, Research and Innovation, Madrid, November 19-21, 2012.

[8] E. Jarošová, M. Lukeš, and J. Winn, "Launching experimential learning and case method based approaches in czech business classes," International Journal of Case Method Research \& Application, vol. 17/4, pp. 515-521, 2005

[9] L. L. Mauffette, J. Erskine, and M. R. Leenders, Teaching with Cases, 3rd ed., London: Ivey Publishing, 2011, ch. 4, pp. 70-73.

[10] E. Jarošová and H. Lorencová, "Encouraging young and beginning teachers competencies," International Journal of Case Method Research \& Application, vol. 21, no. 2, pp. 102-107, 2009.

[11] L. L. Mauffette, J. Erskine, and M. R. Leenders, Writing Cases, 4th ed., London: Ivey Publishing, 2010, ch. 6, pp. 101-104, 108.

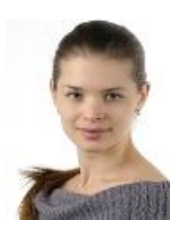

Martina Fischerová is a Ph.D. student at the Department of Managerial Psychology and Sociology at the Faculty of Business Administration, University of Economics, Prague. Her major fields of research are managerial development and experiential learning. As she is a member of a research team focused on active teaching methods and case studies implementation at the Faculty, she also published various papers $(2010,2011,2012)$ with this topic. Her e-mail box is martina.fischerova@vse.cz.

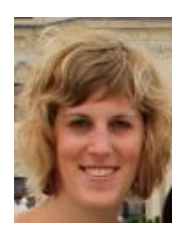

Kateřina Půbalová is a doctoral student at the Department of Managerial Psychology and Sociology at the Faculty of Business Administration, University of Economics, Prague. Previously she has published her research focused on students' study abroad motivation, barriers to thinking and active teaching methods at conferences in the Czech Republic and Spain. She is a part of research team dealing with implementation of active teaching methods at UEP. She is a member of Academic Senate at the Faculty of Business Administration. Her e-mail box is katerina.pubalova@vse.cz. 